\title{
DOES CORPORATE GOVERNANCE AFFECT PERFORMANCE: A STUDY OF SELECT INDIAN BANKS
}

FINANCIAL

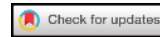

Rekha Handa ${ }^{1}$

\author{
'Assistant Professor Department of Management DAV University, Jalandhar \\ Punjab, India \\ Email:rekha2802@gmail.com Tel:9914201909
}

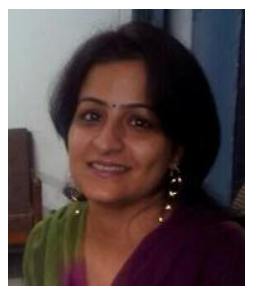

\section{ABSTRACT}

Need of corporate governance in present times is intense especially when the global instances of corporate failures and mismanagement are many. The eminence and uniqueness of banking firms necessitates the need of rational corporate governance practices more so with the added emphasis of Basel Committee on Banking Supervision. The study attempts to examine the role of board structures in the financial performance of select banks over a time span of 2008-15 in India where banking and governance both have hogged the limelight sadly for not very pleasant reasons. Analyzing a small sample of 70 firm entries through panel regression, the study establishes ChairmanCEO duality, average remuneration of directors, board committees and female directors as significant influencers of bank performance. Certain limitations of the study though challenge the generalization of results but it forms a good basis for further research.

JEL Classification: G340, G32, G21, C330.

Contribution/ Originality: The study contributes to the scant literature on governance of Indian banks and its relevance financial performance. The paper assumes importance in the backdrop of recognized potential of Indian banks in the face of revolutionary reforms amidst the growing challenges of financial frauds and deteriorating asset quality.

\section{INTRODUCTION}

Modern businesses characterized by frantic turbulence in the midst of shattering speed of globalization and technology, hyper-competition, disturbing pace of financial innovations, rejuvenated wave of international acquisitions and mergers, have an accentuated need of efficiency, stability and sustainability. Regulators everywhere are scrambling to assess the changes and master the turbulence (Sandeep et al., 2002). Countries and corporations need to have resilient systems with good governance and mechanisms to thrive in the open environments (Kaheeru, 2001).

Corporate governance has recently been the subject matter of major policy decisions and a much hyped issue in media across all countries in the context of its potential role in enhancing the shareholders' value and firm performance. The spate of corporate scandals and frequent instances of mismanagements, self-dealing managerial activities and resulting dilution of faith in corporate systems saw the regulators, corporates and stakeholders re- 
emphasize the need of stringent governance norms and practices. As a result, renewed attention of the researchers and organisations was directed towards analyzing the impact of corporate governance on performance and stability of the firms (Khumani et al., 1998; Doidge et al., 2007; Zulkafli and Samad, 2007). Corporate governance refers to the processes and structures by which the business and affairs of institutions are directed and managed, in order to improve long term share holders' value by enhancing corporate performance and accountability, while taking into account the interest of other stakeholders (Jenkinson and Mayer, 1992).

Financial institutions, dominated by banks are the corner stone of an economy's success in the light of the indispensable functions which they perform viz: payment systems, providing liquidity, reducing participation, transaction and information asymmetry costs and most importantly the critical role of risk management. In the light of their pertinent role, it is essential to ensure the soundness and safety of these institutions and the "governance" of these institutions. The thrust given by The Basel Committee on Banking Supervision (BCBS) to the need to study, understand, and improve the corporate governance of financial entities justifies the extension of study of corporate governance and its effects with respect to these "special" financial entities (De Andres and Vallelado, 2008).

The present study is an attempt to study the effect of board specific measures on the financial performance of select Indian banks over the time period of 2008-2015. The paper draws its importance from the content and context which lend uniqueness to the study and its findings. The paper is a preliminary study to extend the research on corporate governance to the Indian banks which have sprang to prominence for their vibrancy, resilience and volumes even amidst the global crises of 2008. Also, the increasing amount of NPAs posing questions on the stability and efficiency of the Indian banking behemoths and the scandalous transactions with the tainted business tycoon Vijay Mallaya have put to question the relevance and impact of corporate governance in banks.

\section{CORPORATE GOVERNANCE AND BANKS}

The importance of bank governance cannot be overemphasized. Banks play a major role in the economic systems and are the nodal point in the payment mechanisms of the nation. The banking firms undoubtedly exhibit significant differences from the other non-financial institutions which justifies the dropping of financial firms from the sample of firms in other economic sectors. The inherent complexities of banking businesses and differences in their structuring and nature of operations make them an interesting case for corporate governance (Prowse, 1997; Adams and Mehran, 2003). The gigantic role that the banks play for the economic health of a nation calls for special attention towards its governance issues (Caprio and Levine, 2002; Macey and O'Hara, 2003; Levine, 2004). It is this uniqueness of their operations, regulation and global standards that has resulted in this sector's separation from other industries in terms of research in general and governance research specifically. A separate study with focus on banking firms and that too in the less studied developing markets of India can help reach more representative results with clear implications for the booming yet struggling banking industry.

Corporate governance constitutes one of the control mechanisms which help to combat the problems emanating from separation of ownership and management like agency problems, moral hazard and self-centered and self-dealing managerial behavior (Jensen and Meckling, 1976; Fama and Jensen, 1983). The agency theory, therefore, remains a dominant logical dimension for relevance of corporate governance mechanisms in banking firms. The information asymmetry problem is accentuated in financial industries as the consumers of these services lack the expertise and knowledge required to monitor the quality of services and contract, making them an easy prey to manipulations and abusive behavior. The nature of banking services from the conventional times and the eminence in clearing and settlement mechanisms has called for special regulatory measures (Staikouras et al., 2007) which is also justified by the proactive and stringent regulatory guidelines by the BCBS. The highly leveraged banking industry makes it prone to higher risks and also the composite mix of assets comprising of liquid and illiquid assets lands the banks into financial quandary, calling for stringent monitoring and controlling measures. 
Banks, therefore, call for close and distinctive regulation and scrutiny, yet, special regulatory treatment generates novel corporate governance challenges, attracting special attention (Levine, 2004).

The importance of corporate governance in banks and the indispensability of monitoring by board of directors has been acknowledged and explicitly focused by the Basel Committee, noticing that "[c]orporate governance for banking organizations is arguably of greater importance than for other companies, given the crucial financial intermediation role of banks in an economy, the need to safeguard depositors' funds and their high degree of sensitivity to potential difficulties arising from ineffective corporate governance. Effective corporate governance practices, on both a system-wide and individual bank basis, are essential to achieving and maintaining public trust and confidence in the banking system, which are critical to the proper functioning of the banking sector and economy as a whole" (Basel Committee on Banking Supervision (2005) par. 8).

Thus, the unique role, eminent functions and distinct operating environment of banking firms make them a strong case for analysis of corporate governance. The corporate governance theories of agency and resource dependency also justify this area of study and empirical research.

\section{DATA, METHODOLOGY AND VARIABLES}

The present study is a preliminary attempt to explore the corporate governance variables in banking organizations and their effect on performance of banks. The sample consists of nine banks which have been finalized subject to the availability of data across - variables of study and time dimension. The scope of the study is limited to board structure variables: size, composition, duality, committees, meetings and other directorships, which have been documented to be major attributes of governance mechanisms. These mechanisms take on special relevance in banking context owing to the higher informational asymmetries and intense regulation. The paper covers the time period of 8 years spanning across 2008-2015. Therefore, the analysis final balanced panel consists of 72 data entries which have been analyzed using panel regression analysis.

The data for the board structure variables has been culled from the annual reports of these sampled banks. The annual reports were accessed from the data base of 'CAPITALINE' which is a repository of scanned latest annual reports of top companies in India based on market capitalisation.

For the analysis of the data, panel regression has been employed which is one of the most efficient tools to use when the sample spans across time and cross-sectional dimensions. The panel data structure allows us to take into account the unobservable and constant heterogeneity emerging from the specific features of each bank. When the unobserved effect is correlated with independent variables, pooled OLS estimation produces estimators that are biased and inconsistent. An attempt has been made to overcome this challenge by using the fixed effects and random effects after checking the applicability through the Durbin-Wu-Hausman test (also called Hausman specification test).

\subsection{Variables}

To measure the bank performance one of the most common measures of performance has been used, called the return on equity (ROE).ROE is calculated as the ratio of earnings before interest and taxes to the average total bank equity as at the end of each year. The details of the variables used in the study have been presented in Table 1 . The first variable used for corporate governance is the board size representing the total number of members on the board of the company. For board size, the largely shared wisdom is that the larger the board size lesser would be the performance attributing it to the communication and coordination problems and costs involved. Lipton and Lorsch (1992) and Jensen (1993) have been the pioneers for this school of thought, though the positive effects of larger boards on firm performance have also been documented. 
Table-1. Operationalisation of variables

\begin{tabular}{l|l}
\hline Variables & Operationalization \\
\hline \multicolumn{1}{l}{ Dependent Variable } \\
\hline Return on Equity (ROE) & Ratio of net income to the average total bank equity as at the end of each year \\
\hline Independent Variables & \multicolumn{1}{l}{ Total number of directors on the board } \\
\hline Board size & $\begin{array}{l}\text { Dummy variable with value } 1 \text { if CEO and Chairman of the Board are the same } \\
\text { person and o otherwise }\end{array}$ \\
\hline Duality & Total number of board committees that exist \\
\hline Board Committees & Percentage of women directors on the board \\
\hline Female directors & $\begin{array}{l}\text { Total remuneration of directors of the firm divided by the board size (excluding } \\
\text { the sitting fees) expressed in millions of rupees }\end{array}$ \\
\hline Average remuneration & Average of the number of other directorships held by the directors of the firm \\
\hline Other directorships & Number of board meetings held in a year \\
\hline Board meetings &
\end{tabular}

Chairman duality as a variable comes from the argument that a single person as the CEO and Chairman of the board results in unreasonable and excessive power in a single hand resulting in inefficiency and biasness (Solomon, 1993; Daily and Schwenk, 1996). Supporters of duality advocate better internal control systems and less chances of distress in a bank when separate persons assume charge as Chairman and CEO (Simpson and Gleason, 1999). Another aspect of board which is studied is gender diversity represented through the percentage of women directors on the board. Drawing support for their inclusion on board from theories of agency and resource dependency, presence of women directors is expected to enhance monitoring effectiveness and firm value.

Bilimoria and Piderit (1994) submit that previous research indicates the delegation of corporate governance to board committees facilitates effective board and corporate functions and provides a means and structure for effective governance by addressing important corporate concerns. Evidence supports the idea that many important decisions are made in board committees and those decisions affect the performance of the firm (Carter et al., 2010). For this, board committees have been included as an important attribute of boards in banks.

Multiple board appointments are expected to augment reputations of directors as expert decision makers and thus can help build the reputational capital of firm (Fama, 1980; Fama and Jensen, 1983). This reputational advantage lends legitimacy to the corporation (Higgins and Gulati, 2003) and also can work as signal of effective monitoring (D'Aveni, 1990; Shivdasani, 1993). Board meetings are the means through which monitoring and decision making actions are conceived and implemented. Board meetings can help sensitize the boards on strategic issues and thus coordinate for effective solutions and sustainability. According to agency theory, the aim of compensation contracts is to reward managers in such a way that they strive to maximize firm performance and shareholders' wealth. The directors' remuneration should work as a basis for accentuated firm performance and hence the variable has been included for its effects on performance.

Thus, these variables have been included to capture corporate governance in banks and further to investigate their affect on performance of these banking firms. The next section discusses the results of analysis.

\section{RESULTS AND DISCUSSION}

\subsection{Descriptives}

The descriptive characteristics of the variables have been summarized first to understand the characteristics. The mean, median and other statistics are calculated on all the 72 entries to understand the overall pattern in banks with respect to governance characteristics. The table gives an overview of the behavior of variables. The mean return on assets for the 72 firm entries stands at 1.28\% which is more than 1 and augurs well for the growth of these banks over the years. With respect to return on equity, the maximum value is seen as high as $25 \%$. The mean board size stands at 10 which \indicates the tendency of the banking companies to have larger boards vis-à-vis 
other firms and to which the complexities and scale of business stand as a justification. For some of the banks, the board size is seen to be as large as 17 contrasting to the smallest board having only three members.

Table-2. Statistics for the variables of study

\begin{tabular}{|c|c|c|c|c|c|c|}
\hline Variable & $\mathbf{N}$ & Mean & Median & Std. Deviation & Minimum & Maximum \\
\hline $\mathrm{ROA}(\%)$ & 72 & 1.28 & 1.43 & 0.44 & .25 & 1.93 \\
\hline $\mathrm{ROE}(\%)$ & 72 & 16.51 & 17.49 & 4.72 & 3.92 & 25.02 \\
\hline Board Size & 72 & 10.36 & 10.00 & 1.99 & 6 & 17 \\
\hline FEMALE Directors\% & 72 & 7.87 & 9.09 & 6.35 & 0.00 & 23.08 \\
\hline Executive Directors \% & 72 & 18.42 & 12.50 & 11.10 & 8.33 & 71.43 \\
\hline Independent Directors \% & 72 & 57.75 & 57.74 & 14.15 & 14.29 & 90.00 \\
\hline No. of Committees & 72 & 9.78 & 10.00 & 2.35 & 4 & 16 \\
\hline Board Meetings & 72 & 8.56 & 8.00 & 3.23 & 4 & 17 \\
\hline other Directorships & 72 & 3.43 & 3.57 & 2.11 & .30 & 8.25 \\
\hline $\begin{array}{l}\text { Avg. Remuneration } \\
\text { (INR) }\end{array}$ & 72 & 10.75 & 9.07 & 9.27 & .41 & 38.21 \\
\hline
\end{tabular}

Source: Author's calculations

The percentage of female directors on the boards also points out the gender inequalities on the board which prevail across all sectors and sadly lies in tune with the skewed numbers across developed and developing countries. The average of female directors at a dismal low of $7 \%$ justifies the statutory requirements mandated in India for the listed companies. The mean proportion of independent directors is largely governed by the legal requirements (58\%) though instances of lower numbers have also been observed (minimum 14\% and maximum as high as $90 \%$ ). Banks show a strong tendency of having many board committees, to assist the boards, which are in addition to the mandatory nature and number of 3. The mean and median value of 10 emphasizes that banks prefer specialized committees to handle the quantum and complexity of banking transactions. The mean number of board meetings in a year is 8 , which exceeds the statutory requirement of four by a comfortable margin highlighting the needs of coordination and decision making in the midst of complex banking operations. Directors of banks are seen not to have too many other directorships as evidenced by an average of just three and the maximum number also standing at humble 8 . The banking sector offers many competing times and situations which call for greater and close attention of directors, hardly leaving time for other directorships in different firms. The average remuneration for the directors of the sampled banks shows wide range, being as low as 0.41 million and highest being 38.21. The overall average for this stands at 10.75 million rupees indicating many other determinants for compensation other than performance and board variables.

A further peek into these numbers when segregated on the basis of years (as given in Table 2) gives a clearer picture of the characteristics of banks with respect to directors. With respect to the performance measures, ROA and ROE show a gradual increase over the years which point to the fading effects of the subprime crisis over the years. Average board size remains stable with the value being around 10. The numbers with regards to the female directors have seen improvement through the sample period under the influence of the compulsion of woman directors in specified firms as per the Companies Act, 2013. The independent directors on an average do not show much change over the study period.

The number of board committees constituted by the boards of banking companies in India shows an increase on an average moving from 8 to 12 in the study period. The stable and unaffected numbers are also recorded for the other directorships held by the directors of these banks and it stands at 3 in all years. Average remuneration does show an increase which can be justified in the face of changing times, increasing inflation and fierce competition in banking industry which necessitates these compensation packages to increase and provide a negotiation basis. 
Table-3. Year wise mean values of the variables

\begin{tabular}{|c|c|c|c|c|c|c|c|c|}
\hline Year & 2008 & 2009 & 2010 & 2011 & 2012 & 2013 & 2014 & 2015 \\
\hline Observations & 9 & 9 & 9 & 9 & 9 & 9 & 9 & 9 \\
\hline $\mathrm{ROA}(\%)$ & 1.03 & 1.08 & 1.20 & 1.31 & 1.39 & 1.43 & 1.40 & 1.41 \\
\hline Board Size & 10.56 & 10.44 & 11.22 & 10.22 & 9.78 & 10.11 & 10.33 & 10.22 \\
\hline FEMALE Directors $\%$ & 5.45 & 6.55 & 6.02 & 6.32 & 9.23 & 8.73 & 7.90 & 12.73 \\
\hline No. of Committees & 8.22 & 8.00 & 8.22 & 9.22 & 10.11 & 10.44 & 11.67 & 12.33 \\
\hline Board Meetings & 9.00 & 8.44 & 7.89 & 8.67 & 8.22 & 7.89 & 9.11 & 9.22 \\
\hline Other Directorship & 3.64 & 3.79 & 3.57 & 3.23 & 3.26 & 3.24 & 3.08 & 3.61 \\
\hline Avg. Remuneration (INR) & 7.10 & 8.34 & 7.57 & 9.47 & 11.71 & 12.53 & 13.34 & 15.95 \\
\hline
\end{tabular}

\subsection{Panel Regression}

The objectives of study, nature of sample and variables called for understanding the relationship of dependent variables across different time periods and cross-sections. In order to examine the impact of board variables on the performance of banks, pooled estimates with ROE as the dependent variable and board variables including board size, board independence, female directors, board committees, duality, other directorships, board meetings and directors' remuneration as independent variable are calculated. To take care of the inherent and unobservable heterogeneity emerging from the distinctness of each bank and as necessitated by the rejection of redundant fixed effect ratio, from pooled results the study moves to the fixed effects model. The pooled estimates in cases of heterogeneity in dependent variable and correlation of these unobservable effects with the independent variable generate biased estimators unfit for generalizations and conclusions. To ensure the robustness of the results, fixed effects model is checked for the random effects using the Hausman specification test. The insignificant results of this test establish the absence of random effects in the model and thus the conclusions are drawn from the fixed effects model. The model presented in Table 3 has been checked and corrected for the assumptions of autocorrelation, heteroscedasticity and multi-collinearity.

Table-4. Results of fixed effects panel regression

\begin{tabular}{|c|c|}
\hline $\begin{array}{l}\text { Dependent Variable: ROE } \\
\text { Independent Variables }\end{array}$ & MODEL 1 \\
\hline Constant & $\begin{array}{l}21.59 \\
(5.385)\end{array}$ \\
\hline Board Size & $\begin{array}{l}0.128 \\
(0.533) \\
\end{array}$ \\
\hline Duality & $\begin{array}{l}1.537 \\
(2.269)^{* * *} \\
\end{array}$ \\
\hline Proportion of Female Directors & $\begin{array}{l}-0.176 \\
(-4.448)^{*} * *\end{array}$ \\
\hline Board Committees & $\begin{array}{l}-0.644 \\
(-2.932)^{*} * *\end{array}$ \\
\hline Average Director Remuneration & $\begin{array}{l}0.093 \\
(2.066)^{* * *} \\
\end{array}$ \\
\hline Other Directorships & $\begin{array}{l}0.018 \\
(0.047)\end{array}$ \\
\hline Board Meetings & $\begin{array}{l}-0.005 \\
(-0.309)\end{array}$ \\
\hline $\mathrm{R}^{2}$ & 0.826 \\
\hline Adjusted $\mathrm{R}^{2}$ & 0.747 \\
\hline Number of Observations & 72 \\
\hline F statistic & $\begin{array}{l}10.548^{* * * *} \\
(0.000)\end{array}$ \\
\hline
\end{tabular}

Note: One*, two** and three asterisks**** indicate statistical significance at the level of $10 \%, 5 \%$ and $1 \%$, respectively. Tstatistics are provided in the parentheses. 
The results of the analysis indicate a robust regression model with significant $\mathrm{F}$ - ratio establishing the model as a good fit. The model, as supported by the value of adjusted $\mathrm{R}^{2}$, explains almost 75 percent of the variations in the performance of the sampled banks as captured by ROE. Board size displays a positive relation to the performance indicating the capability of larger boards to positively influence the financial performance which though contrasts to many of the results documented in prior studies. The complexity and scale of Indian banking operations can probably be put forth as the explanation for this direction but the lack of statistical significance of the results leaves the debate on this contentious issue open. Duality, the separation of roles of Chairman of the board and CEO bears a significant positive relation with the performance measure promising efficiency and independence and thus better results as professed by Solomon (1993) and Daily and Schwenk (1996). Banks characterized by larger opacity and information asymmetry seem to send better assurances of efficient management when CEO and Chairman are separate persons. Presence of female directors negatively affects the bank's financial performance and this relationship stands the test of statistical significance. The explanations to this direction of relationship can possibly emerge from the limited number of women directors on the Indian boards and the rare numbers are picked from amongst the close circle of family, friends and relatives. The promising effects of diversity thus fail to translate into performance as propounded by the gender diversity theorists and also the small numbers indicate tendencies of tokenism which negate rather than add to the returns. Board committees, which were hypothesized to enhance the quality of decisions of board and strategic implementation, affect the performance and that too negatively as evidenced by the significant negative coefficient of this variable in the panel results. The larger number of board committees as was professed for the board size, possibly enhance the problems of coordination and communication resulting in conflicts and differences and hence pull down the performance of banks. The vibrancy and volumes in the banking industry call for efficient and effective board practices, however these results call for more comprehensive investigation with larger sample and better controls.

Compensation and remuneration remain an important determinant of performance in all sectors and at all levels. The relationship of directors' remuneration with performance, however, remains a moot issue with equivocal results. The sample demonstrates a significant positive relation of average remuneration pocketed by directors with the return on equity of the banking companies signifying that they do work as positive motivators pushing the directors to better action which is translated into returns. Other directorships which the directors hold with other companies signify the levels of networking and linkages which are necessary in the light of the resource dependence theory. The positive relation does establish the truth of this theory of corporate governance but lack of significance calls for comprehensive and deeper insights. Number of times the board members meet during the year to contemplate, strategize and implement their strategies is definitely an indicator of board workings and performance. The results indicate ainsignificant negative relation to performance which point out that more board meetings, probably due to the costs involved, financial and administrative considerations, hamper the financial performance of the firms.

Overall, the results of this limited sample in the vibrant markets of India and in the fluid banking industry present good and statistically sound results but leave the room for better and comprehensive research efforts in this field. The results are definitely suggestive of distinct nature of banking firms and Indian economy but call for more intense investigation with more attributes of corporate governance and larger sample.

\section{CONCLUSION}

The present study is motivated by the significance assumed by corporate governance research in present times laced with stringent regulations, stiff competition and disturbing regularity of corporate scams. Eminence occupied by corporate governance in financial research and the prominent global space occupied by Indian economy make the present study an effort in the right direction. The context of present study - the Indian banking industry, its volumes and vigor during and beyond the recent global meltdown lend additional relevance to the study in hand. A 
preliminary effort has been made to check the relevance and effect of corporate governance on the financial performance of a few selected Indian banks spanning across a time period of eight years. The finalization of sample was based on availability of data and thus study was conducted on eight banks. Board variables have been employed to capture the corporate governance mechanisms in these banks and drawing support from the relevant literature return on equity (ROE) has been used as the performance measure. Analyzing the data across eight years and for different banks using panel regression analysis it was found that board variables do affect that performance of banks. Significant effects have been found for CEO duality, board committees, percentage of female directors on the boards, and average remuneration of the directors.

The results do indicate the influencing effects of board variables as an attribute of corporate governance system but the limitation of sample calls for more rigorous analysis for generalizability of results. Further research with additional measures of performance and more representative samples is required to arrive at dependable conclusions. The present effort can be appreciated as an initial endeavor to explore effects of corporate governance in Indian banks which are otherwise excluded from studies due to their complexities, operating differences and regulatory differences. Banking sector, though being distinct from other non-financial institutions, cannot be left out from governance studies and more so the widely talked about and deep rooted Indian banking sector.

Funding: This study received no specific financial support.

Competing Interests: The author declares that there are no conflicts of interests regarding the publication of this paper.

\section{REFERENCES}

Adams, R. and H. Mehran, 2003. Is corporate governance different for bank holding companies?.FRBNY Economic Policy Review, April. pp: 123-142.

Basel Committee on Banking Supervision, 2005. International convergence of capital measurement and capital standards: A revised framework. Retrieved from http://www.bis.org/publ/bcbs118.htm [Accessed 12 July, 2017].

Bilimoria, D. and S.K. Piderit, 1994. Board committee membership: Effects of sex-based bias. Academy of Management Journal, 37(6): 1453 -1477. View at Google Scholar | View at Publisher

Caprio, G. and R. Levine, 2002. Corporate governance of banks: Concepts and international observations. Paper Presented at the Global Corporate Governance Forum Research Network Meeting, Mexico City, April 5.

Carter, D.A., F. D'Souza, B.J. Simkins and W.G. Simpson, 2010. The gender and ethnic diversity of us boards and board committees and firm financial performance. Corporate Governance: An International Review, 18(5): 396-414. View at Google Scholar | View at Publisher

D’Aveni, R., 1990. Top managerial status and organizational bankruptcy. Organizational Science, 1(2): 121-142. View at Google Scholar $\mid$ View at Publisher

Daily, C.M. and C. Schwenk, 1996. Chief executive officers, top management team, and boards of directors: Congruent or countervailing forces? Journal of Management, 22(2): 185-208. View at Google Scholar $\mid$ View at Publisher

De Andres, P. and E. Vallelado, 2008. Corporate governance in banking: The role of the board of directors. Journal of Banking \& Finance, 32(12): 2570-2580. View at Google Scholar | View at Publisher

Doidge, C., A. Karolyi and R. Stulz, 2007. Why do countries matter so much for corporate governance? Journal of Financial Economics, 86(1): 1-39. View at Google Scholar | View at Publisher

Fama, E., 1980. Agency problems and the theory of the firm. Journal of Political Economy, 88(2): 288-307. View at Google Scholar View at Publisher

Fama, E. and M. Jensen, 1983. Separation of ownership and control. Journal of Law and Economics, 26(2): 301-326. View at Google Scholar

Higgins, M.C. and R. Gulati, 2003. Getting off to a good start: The effects of upper echelon affiliations on underwriter prestige. Organization Science, 14(3): 244-263. View at Google Scholar | View at Publisher 
Jenkinson, T. and C. Mayer, 1992. The assessment: Corporate governance and corporate control. Oxford Review of Economic Policy, 8(3): 1- 10. View at Google Scholar | View at Publisher

Jensen, M.C., 1993. The modern industrial revolution, exit, and the failure of internal control systems. Journal of Finance, 48(3): 83 1-880. View at Google Scholar | View at Publisher

Jensen, M.C. and W.H. Meckling, 1976. Theory of the firm: Managerial behavior, agency costs and ownership structure. Journal of Financial Economics, 3(4): 305-360. View at Google Scholar $\mid$ View at Publisher

Kaheeru, V., 2001. Institute of corporate governance of Uganda. Manual. Lipton, M. and J.W. Khumani, R. and Stone, A. and Hurly, K. (1998). Business environment and corporate governance: Strengthening incentives for private sector performance. The World Bank/IMF Annual Meetings, 1998, Background Papers.

Khumani, R., A. Stone and K. Hurly, 1998. Business environment and corporate governance: Strengthening incentives for private sector performance. The World Bank/IMF Annual Meetings, 1998, Background Papers.

Levine, R., 2004. The corporate governance of banks: A concise discussion of concepts and evidence. Policy Research Working Paper No. 3404, World Bank, Washington, DC.

Lipton, M. and J. Lorsch, 1992. A modest proposal for improved corporate governance. Business Lawyer, 48(1): 59-77. View at Google Scholar

Macey, J.R. and M. O’Hara, 2003. The corporate governance of banks. Federal Reserve Bank of New York Economic Policy Review, 9(1): 91-107.

Prowse, S., 1997. The corporate governance system in banking: What do we know? PSL Quarterly Review, 50(200): 11-40. View at Google Scholar

Sandeep, A., A.B. Patel and B. Lilicare, 2002. Measuring transparency and disclosure at firm-level in emerging markets. Journal of Finance, 3(4): 325-337. View at Google Scholar | View at Publisher

Shivdasani, A., 1993. Board composition, ownership structure, and hostile takeovers. Journal of Accounting and Economics, 16(1/3): 167-198. View at Google Scholar | View at Publisher

Simpson, W.G. and A.E. Gleason, 1999. Board structure, ownership, and financial distress in banking firms. International Review of Economics and Finance, 8(3): 281-292. View at Google Scholar | View at Publisher

Solomon, W.J., 1993. Crisis prevention: How to gear up your board. Harvard Business Review, 71(1): 68-75. View at Google Scholar

Staikouras, P.K., C.K. Staikouras and M.E.K. Agoraki, 2007. The effect of board size and composition on European bank performance. European Journal of Law and Economics, 23(1): 1-27. View at Google Scholar | View at Publisher

Zulkafli, A.H. and F.A. Samad, 2007. Corporate governance and performance of banking firms: Evidence from Asian emerging markets. In Issues in Corporate Governance and Finance. Emerald Group Publishing Limited. pp: 49-74.

Views and opinions expressed in this article are the views and opinions of the author(s), Asian Economic and Financial Review shall not be responsible or answerable for any loss, damage or liability etc. caused in relation to/arising out of the use of the content. 